\title{
Cultura Cultura
}

Revista de Histria Teroria das ldeaias - Revista de História e Teoria das Ideias

Vol. 28 | 2011

Das leituras e dos leitores - Entre filologia e história

\section{Anita Mercier, Guilhermina Suggia: Cellist}

\section{Teresa Cascudo}

\section{OpenEdition}

Journals

Edição electrónica

URL: http://journals.openedition.org/cultura/324

DOI: $10.4000 /$ cultura.324

ISSN: 2183-2021

\section{Editora}

Centro de História da Cultura

\section{Edição impressa}

Data de publição: 1 junho 2011

Paginação: 289-290

ISSN: 0870-4546

\section{Refêrencia eletrónica}

Teresa Cascudo, « Anita Mercier, Guilhermina Suggia: Cellist », Cultura [Online], Vol. 28| 2011, posto online no dia 17 maio 2013, consultado a 22 setembro 2020. URL : http://journals.openedition.org/ cultura/324 ; DOI : https://doi.org/10.4000/cultura.324 


\title{
Anita Mercier, Guilhermina Suggia: Cellist, Aldeshot, Ashgate, 2008
}

\author{
Teresa Cascudo*
}

A história da interpretação é um campo de investigação que, em grande medida, está ainda por desenvolver em Portugal. Esta não é uma lacuna específica da musicología nacional, visto ser relativamente recente o interesse académico pelo seu estudo fora do domínio da pedagogía. Por isso, são particularmente bem-vindos os estudos que, tal como este da autoria de Anita Mercier, reivindicam a importância que os intérpretes têm na prática musical. Gulhermina Suggia foi um caso excepcional de genialidade musical, cujo desenvolvimento artístico foi possível graças ao estimulante meio familiar e social que Ihe calhou viver. Nascida no Porto em 1885, começou a tocar o violoncelo quando apenas tinha 5 anos, apoiada pelo seu pai, também instrumentista. Sendo ainda uma criança, integrou-se no meio musical da sua cidade natal, partipando directamente no renascimento musical orientado por Bernardo Moreira de Sá, o fundador do Orpheon Portuense. O Porto, juntamente com Lisboa, era na altura o centro da actividade dos principais instrumentistas profissionais, cujas carreiras, no caso dos mais talentosos, sempre foram desenvolvidas fora do país. Por um lado, evidenciou-se nesses anos a importância das conexões internacionais, e, por outro, a existência de um tecido social no qual se inseriu um tipo de prática de iniciativa privada ligada à música instrumental que, entre outras características, combinava o amadorismo e o profissionalismo. Começou a ser alterada apenas a partir de finais da década de 30, coincidindo com a implantação da rádio e com a intervenção do Estado em matéria cultural. Suggia foi um dos melhores frutos nascidos nesse terreno. Encontrou uma rede social que, apesar de minoritária, outorgava ao seu talento um valor significativo e, com o seu apoio, conseguiu completar a sua formação fora de Portugal, sob a orientação de um dos melhores pedagogos do violoncelo, Julius Klengel. O resultado foi uma fulgurante carreira internacional, iniciada quando era ainda estudante em Leipzig.

O trabalho de Anita Mercier tem, em primeiro lugar, o enorme mérito de fixar a biografia da violoncelista, que, até há bem pouco, ainda apresentava questões por esclarecer. Os trabalhos anteriores de Fátima Pombo e Anamaría Ferrin, assim como o empenho divul-

* INET-Md - Faculdade de Ciências Sociais e Humanas da Universidade Nova de Lisboa. 
gativo de Virgílio Marques no blogue da Associação Guilhermina Suggia, já tinham trazido à luz numerosa informação desconhecida. Mercier, por seu turno, tem conseguido dar um passo em frente, ao integrar o seu pormenorizado trabalho sobre as fontes documentais numa narrativa fluida, que aborda as facetas principais da vida da artista. A autora faz isto com uma sensibilidade assinalável, descrevendo os detalhes menos agradáveis da sua vida íntima de forma inteligente, sempre respetuosa com a sua memória. Mercier não assume uma perspectiva abertamente feminista, porém não deixa de reconstruír as dificuldades derivadas dos preconceitos de género com as quais Suggia teve de se confrontar durante todo o seu percurso vital e artístico. $O$ episódio do seu encontro e convivência posterior com o violoncelista Pablo Casals - na opinião da crítica britânica, se ele era o "rei" do violoncelo, ela era a "rainha" - é talvez aquele que ilustra da melhor forma as dificultades com as quais se deparou para conciliar a vida doméstica e a artística. Ambos viveram um amor apaixonado que, tal como a citada Anamaría Ferrin tinha mostrado anteriormente, tinha sido completamente banido nos estudos biográficos dedicados ao instrumentista espanhol. Resulta difícil enquadrar uma personalidade artística brilhante e sedutora como, pelos vistos, era a de Suggia nos arquétipos moldados pela nossa cultura patriarcalista. $O$ certo é que, apesar de ser mais nova e de ter recebido algumas aulas privadas de Casals durante as visitas deste a Portugal antes de ela ter partido para Leipzig, quando se evidenciou que o desenvolvimento a par das carreiras de ambos era impossível, Suggia optou pela liberdade. Não devemos esquecer que ela foi uma das pioneiras num instrumento musical que, antes dela, era considerado exclusivamente masculino.

Anita Mercier serve-se de uma perspectiva cronológica e explica, com um estilo muito ameno, a evolução que levou a menina-prodígio a transformar-se numa das instrumentistas mais respeitadas da primeira metade do século XX. Dá as chaves que permitem perceber as razões pelas quais ocupa um lugar secundário na memória dos melómanos. Proporciona, além do mais, uma completa visão de conjunto das obras que faziam parte do seu repertório e da sua actividade concertística. É apenas de notar a ausência de uma análise estilística específica dos seus registos sonoros disponíveis, dos quais Mercier proporciona o correspondente catálogo, compreensível, no entanto, num trabalho excelente, mas de pendor tradicional. 